\title{
CONCOMITANT OF INSIDE-SHAREHOLDING, GROUP AFFILIATION AND FIRM VALUE: EVIDENCE FROM PAKISTAN
}

\author{
WASEEMULLAH ${ }^{1}$, Safdar Husain TAHIR (D2* ${ }^{*}$, Muhammad Shafiq KALEEM ${ }^{3}$, \\ Tahirah KANWAL ${ }^{4}$, Muhammad Umer QUDDOOS (DD 5 \\ ${ }^{1,4}$ Department of Management Sciences, University of Gujrat, Pakistan \\ ${ }^{2}$ Lyallpur Business School, Government College University, Faisalabad, Pakistan \\ ${ }^{3}$ Department of Management Sciences, Virtual University of Pakistan, Pakistan \\ ${ }^{5}$ Department of Commerce, Bahauddin Zakariya University, Multan, Pakistan
}

Received 26 July 2020; accepted 23 March 2021

\begin{abstract}
The present study inspects the comparative effects of inside shareholding on firm value for group-affiliated firms and non-group-affiliated firms in Pakistan. The research uses the excess-value as a performance measure by employing a chop-shop approach in treatment effects regression model (TERM). The results reveal that lower level and higher level inside shareholding negatively associated with firms' value. However, it positively relates at a moderate level. Also, inside shareholding-value relationship differs significantly for group-affiliated firms and non-group-affiliated firms. Firms with inside shareholding at lower level appear to more visible in business groups, and these firms show adverse firms' value consistent with divergence of interest effect. Nevertheless, inside ownership firms at a higher level, namely standalone firms, negatively affect firm value with entrenchment effect. The findings also confirm non-linearity in inside shareholding-firm value relationships.
\end{abstract}

Keywords: inside shareholding, firm value, excess value, business groups, incentives effect, entrenchment effect.

JEL Classification: C92, G32, E22, Z21.

\section{Introduction}

Shareholding is separate from management in public corporations that is a significant reason for agency conflicts. Inside shareholding-performance relationship receives greater attention of the researchers in the academics of finance. Inside shareholdings align the insiders' interests with those of minority shareholders, helping control the agency problem. A substantial ownership stake of the insiders ${ }^{1}$ It motivates them to monitor firm because of the "incentives effect" and contributes to increased performance (Jensen, 1986; Kamardin, 2014; Katper et al., 2018). It discourages the insiders' motivation in tunnelling firm's assets by various channels, including inside trading, transfer pricing, in-efficient or over-investment, employing incompetent management and excessive perquisites (Djankov et al., 2008). The minority shareholders discount the

1 Insiders are the individuals or a group of people who own and control a firm. share value, and insiders lose more weight than personal benefits. Incentive alignment serves as a useful monitoring tool that promotes the external shareholders' safety effectiveness and restricts the insiders' potential to make private gain insiders at exterior make (Bertrand et al., 2002; La Porta et al., 2000; Young et al., 2008; Shahab-u-Din \& Javid, 2011; Ali et al., 2020).

Conversely, insiders' shareholdings may have an inverse effect on the firm's performance consistent with the "entrenchment effect". Having full control over the corporate assets, the dominant insiders with large ownership stakes may exert entrenched behaviour as they are least concerned with the external monitoring of capital markets and internal monitoring of the board (Banchit \& Locke, 2011). They may be indulged in the exploitation of minority shareholders that determents the firm's performance. They decide how to run a firm and distribute profits among the firm's owners (Claessens et al., 2002; Wellalage \& Locke, 2014). The external shareholders are doubtful whether they can receive gains in proportion to

${ }^{*}$ Corresponding author. E-mail: drsafdargcuf@gmail.com 
their shareholdings because dominant insiders possess the ability to deprive them of their due rights. There may be severe agency conflicts between dominant insiders and external shareholders (Laeven \& Levine, 2007; Bebchuk \& Weisbach, 2010; Filatotchev et al., 2013).

Inside shareholding-performance relationship may not be linear. It depends upon the levels of insiders' shareholdings whether these affect positively or negatively the firms' performance. Inside shareholdings at lower levels affect firms' performance differently than at a moderate level. Inside shareholding-performance relationship may be quadratic (Waseemullah et al., 2017), U shape (Morck et al., 1988; Kamardin, 2014; Hoang et al., 2017) or inverted U shape (Belghitar et al., 2011; Wellalage \& Locke, 2014). Itturalde et al. (2011) find that insiders' shareholding positively affects family firms' performance at a lower level when it ranges between $0-35 \%$ whereas it affects negatively at an intermediate level between 35-70\%. Again the relationship turns to positive at a higher level of $70 \%$ and above inside shareholdings category. Arshad and Javid (2014) observe positive performance impacts of inside shareholdings at a moderate level, e.g., 10-25\% category. However, it does not significantly affect firms' performance at a lower level, e.g., 0-10\% type and higherlevel, e.g., 25\% and above category.

Institutional setting plays a vital role in the inside ownership-performance relationship. Product, labour and capital markets are needed to accomplish various business needs in the country. Those countries which lack the efficient markets are characterised by higher transaction costs, risk and uncertainty. Business groups (BGs) emerge in response to market failures, and these are well pronounced in emerging countries like Pakistan. BGs are internal networks that enable their member firms to cope with the under-developed nature of institutional infrastructure (He et al., 2013). The insiders (group headquarters) extend their control than cash flows rights. Agency conflicts are troublesome in group affiliated firms (GAFs) that may affect firms' performance adversely. Agency theorists propose that insiders' shareholding concentration is a useful monitoring tool mitigating agency conflicts among insiders and minority shareholders (Villalonga \& Amit, 2006; Chang, 2003; McKee et al., 2014).

BG affiliation may have a strong contingent effect on the inside shareholding-performance relationships in the Pakistani context. In GAFs, inside shareholdings have a two-sided impact on firms' performance. First, at a lower level of inside shareholdings, it has an inverse relationship with firm performance due to divergence of interest of insiders creating agency problems between insiders and minority shareholders (Gordon \& Nicholson, 2010; Kidwell, 2008). The insiders (ultimate controllers) of GAFs are highly benefited in making private gains. Conversely, insiders' shareholdings at higher level positively affect insiders as insiders are motivated in the firm's monitoring due to convergence of interest effect. It aligns their interests with those of external shareholders' incentives that discourage their tunnelling potential.
Conversely, two-sided outcomes are possible for inside shareholding-performance relationships for non-group affiliated firms (NGAFs). Inside ownership at a lower level is positively related to firm performance. Because insiders may remove from the board quickly, they are keenly involved in monitoring the firm. Inside ownership at a higher level is inversely related to firm performance due to entrenchment effect. The insiders become powerful because of their large stakes of ownership, and they may have self-serving, opportunistic, rather value-maximising behaviour (Martin et al., 2017).

The present study contributes to the existing literature on corporate finance in many folds. First, it examines the impact of inside shareholdings on firms' value. Second, the study investigates the effects of linearity \& various degrees of inside shareholding on GAFs. To determine the comparative performance effects for GAFs relative to unaffiliated firms "Excess value" is used to measure firm value. It is estimated through Chop Shop methodology. It focuses on finding out if the nature of agency conflicts varies substantially in GAFs than unaffiliated firms and the implications on firms' value. Finally, Heckman (1979) styled endogenous self-selection treatment effect model is used to avoid endogeneity problems. These issues are not studied earlier in an emerging country context like Pakistan. The study also provides useful information to managers, policymakers, and regulatory bodies responsible for the country's governance mechanism.

\section{Literature review and hypotheses development}

Many studies examine the insider ownership-performance relationship and find mixed results. Some studies find positive relation (Kaserer \& Moldenhauer, 2008; Hu \& Zhou, 2008; Katper et al., 2018), few studies observe negative (Fahlenbrach \& Stulz, 2008; Shah et al., 2011; Ali et al., 2020; Vintilă \& Gherghina, 2015). Yet some others find no relationship (Demsetz \& Lehn, 1985; Abdullah et al., 2011; Hamza \& Suman, 2018). Those researchers who find a positive relationship relate it with incentives effect and others who see a negative relationship relate it with entrenchment effect or divergence of interest effect.

Hamza and Suman (2018) employ a sample of 50 firms listed on the Bombay Stock Exchange and observe that inside ownership shows the insignificant relationship with firms' performance in India. Kaserer and Moldenhauer (2008) employ a sample of 648 companies covering the 2003-2007 period and find positive inside shareholdingperformance relationship in Germany. Similarly, Li et al. (2007) confirmed a direct connection between managerial shareholding and performance in China's state-owned enterprises. These were privatised during 1992-2000. Berke-Berga et al. (2017) take firms listed on the Baltic States stock exchanges and observe a positive association of inside shareholding on return on assets. In contrast, it is insignificantly related to Tobin's Q. Zondi, and Sibanda (2015) examine inside ownership-performance relationship by employing a sample of companies listed on JSE 
for 2010-2013. The regression results indicate a positive relationship, and however, results from 2SLS reveal no significant association with firms' performance.

Fahlenbrach and Stulz (2008) examine the connection inside- shareholdings and firms' value in the United States. They suggest that inside shareholding negatively affects a firm's value. The researchers observe that average changes in inside shareholding are remarkably negative in US firms during 1988-2003. Managerial ownership is more likely to decrease during the period's firms' performance is good. However, it is not more likely to increase during the periods when the firm' performance is terrible.

Further, a large increase in managerial ownership is not related to firms' value. Ali et al. (2020), based on the meta-analysis of 67 studies across developed and developing countries, conclude that inside shareholding strongly negatively affects firms' performance in developing countries. However, inside ownership seems not influential in affecting firms' performance in developed countries.

Several scholars propose that insiders' shareholdingperformance relationship is non-linear (Khan et al., 2014; Coles et al., 2012; Benson \& Davidson, 2009; Hoang et al., 2017). The positive or negative outcomes primarily depend upon levels of insiders' shareholdings. Mueller and Spitz (2001) take a sample of 1300 firms and find a non-linear relationship in Germany. The findings suggest that inside shareholdings enhance firms' performance until it reaches a certain threshold level, e.g., $80 \%$ and then performance started to decline beyond that level of ownership. Kamardin (2014) categorises inside shareholding into two categories, e.g., family shareholding and non-family shareholding. The study finds non-linear inside shareholding-performance relationship in Malaysia. However, the strength of the relationship is relatively healthier for family inside-shareholding than non-family inside shareholding. Tobin's $Q$ value decreases if the family inside-shareholding is less than $28.29 \%$, whereas the corresponding figure is $31.38 \%$ for non-family inside shareholding. Beyond these limits, Tobin's Q increases.

Belghitar et al. (2011) observe inverted U shaped the insiders' shareholdings and firms' performances. They find insiders' shareholding hiders firms' performance at initial levels and again at higher levels, enhancing firms' performance at the intermediate level. Morck et al. (1988) find varying impacts of inside shareholdings on firms' value for $0-5 \%, 5-25 \%$ and $25-100 \%$ categories in the USA. The results indicate a $U$ shape relationship. Firm's value increases with inside ownership at $0-5 \%$ \& $25 \%$ and above levels, decreasing to 5-25\%. The results support both "incentives effect" and "entrenchment effect". Firms with low managerial ownership are free from managerial entrenchment, and managers are highly motivated in increased firms' performance because their survival is associated with firms' performance. With the increase in managerial ownership, managers are entrenched, and therefore, it hinders firms' performance. At a higher level of managerial ownership, adverse effects of entrenchment disappear as managers' incentives are linked with firms' performance and enhance performance. The findings of the study of Itturalde et al. (2011) also suggest the positive and negative association between insiders' shareholdings and firms' profitability. They find that insiders' shareholdings at lower levels [0-35\%] increase firms' performance, it decreases performance at higher levels [35-70\%] and again increases at above $70 \%$ levels.

Along the same lines, De Miguel et al. (2005) find a U-shape relationship for $0-35 \%, 35-70 \%$ \& above $70 \%$ in Spain. Ruan et al. (2011) also report positive-negativepositive inside the ownership-performance relationship. Firm performance increases when inside ownership ranges between $0-18 \%$, decrease for $18-64 \%$ category, and expansions for above 64\% category. Pant and Pattanayak (2007) study takes 1,833 firms listed on the Bombay Stock Exchange and reports a positive-negative-positive relationship in India. Firms' value increases with increased inside shareholdings up to $20 \%$ level and then it decreases between $20-49 \%$ level and finally increases again above $49 \%$. Hoang et al. (2017) take manufacturing firms listed on the Ho Chi Minh Stock Exchange. They use to system-GMM estimator technique to investigate the impact of inside shareholdings on firms' performance. Tobin's $Q$ is used as a performance measure. The findings indicate that inside shareholding-performance relationship is nonlinear e.g., positive-negative-positive. The results suggest that ownership associated incentives to managers are more important than external monitoring of the shareholders and are very effective in enhancing the firms' governance quality.

Lins (2003) examines 1,433 firms of 18 countries and observe negative relationships between insider shareholdings and firms' performance. He takes insiders' shareholding ranges between $5-20 \%$. These insiders are also called block holders. However, results do not indicate a damaging relationship for the same category in the presence of outside block holders. The findings clearly show that external block holders (block holders other than insiders) are equipped with higher monitoring abilities than insiders. Therefore, they are beneficial in controlling agency conflicts among shareholders, e.g., such as insiders and minority shareholders.

In the Pakistani context, Abdullah et al. (2011) take 158 PSX listed firms for 2003-2008 periods and observe an insignificant association of group shareholding with firms' performance. However, group shareholding squared is inversely related to firms' accounts. The findings support to entrenchment effects. The results suggest that dominant controllers engage in tunnelling GAFs' resources at minority shareholders' cost, thus detrimental to firm performance. Shah et al. (2011) use 67 PSX listed companies for the 2005 year. The results show the adverse performance effects of insiders' shareholdings. The firms with the lowest insiders' shareholdings [1.5\%] enjoy higher performance than medium levels of insiders [9.1\%]. Further, firms with higher insiders' shareholdings ([9.9\%] show the lowest profitability. Similarly, Khan and Nouman (2017) employ 177 firms for 2004-2013 period 
and observe the inverse relation of inside shareholdings with firms' performances.

Contrarily, Waseemullah et al. (2017) observe opposite results. They take a sample of PSX listed GAFs for 20 the 04-2012 period. They make a return on assets as a performance measure. The results show a quadratic relationship (negative-positive) between insiders' shareholdings and firms' performances. Insiders' shareholding is negatively related to earning. However, insiders' shareholding squared is positively linked with GAFs' profitability. The results support to incentives effect. The insiders lack incentives alignment at a lower level of inside ownership and are motivated to make personal wealth. It restricts the tunnelling potential of insiders' as insiders' shareholdings exceed specific threshold levels because insiders' incentives are converged to minority shareholders' interests.

Correspondingly, Arshad and Javid (2014) take 140 PSX listed firms. The findings show an inverted U-shape relationship. The effect of insiders' shareholdings at moderate levels $[10-25 \%]$ is positive. It is insignificantly related to firms' performance at lower levels [0-10\%] and higher levels [above 25\%]. The findings propose that insiders are useful in firms' monitoring only for $10-25 \%$ shareholdings category. This shareholding level is free of insiders' entrenchment and enough to influential heir incentives with minority shareholders' interests. Interestingly, Shahab-u-Din and Javid (2011) take a sample of 60 non-financial firms listed on Pakistan Stock Exchange covering 2000-2007 and observe non-linearity in the relationship of inside shareholding on firm performance in Pakistan. Firm's performance increases if an inside shareholding is at a low level, e.g., $0-5 \%$ \& at a moderate level, e.g., $5-25 \%$. Conversely, it negatively affects a firm's performance beyond the $25 \%$ level. The findings support both incentives effect and entrenchment effect.

Hypothesis 1a. There is a significantly positive effect of inside shareholdings on firms' performance.

Hypothesis $1 b$. There is a significantly negative effect of inside shareholdings on firms performance.

Hypothesis 2. There are significantly varying effects of inside shareholdings on the performance of GAFs than NGAFs.

Hypothesis 3. There is a non-linear relationship between inside shareholdings and firms' performance.

\section{Data and methodology}

Our study employs a sample of 272 Pakistan Stock Exchange-listed non-financial firms. The selection includes data for 173 GAFs and 99 NGAFs for the period of 2004-2012. The modified Chop Shop methodology is used to calculate the excess value. ${ }^{2}$ A positive excess value shows higher performances of GAFs than NGAFs operating in the same industry, and a significantly negative

\footnotetext{
2 To investigate comparative performances' effects of inside ownerships for GAF relative to NGAFs, a well-documented performance measure of "Excess value" has been used (Berger \& Ofek, 1995; Lee et al., 2008).
}

value means lower profitability of GAFs than NGAFs in the industry.

The study is subject to certain issues related to estimation. The most important concern is the endogeneity problem resulting from omitted variable bias, selection bias and reverse causality. For instance, few unobservable variables: the firm's internal governance system, resource capabilities that might affect the firm's performances, and these have not been considered regressors. Further, group affiliation status (whether a firm is GAF or NGAF) may correlate with the error term. There may be few variables like firm's growth, risk level and profitability position, etc., those may affect the probability of a firm to be selected as GAF by group headquarters and these variables also show the impact on firms' performances (Choe et al., 2014; Bae et al., 2011). Hence, the study employs Heckman (1979) styled endogenous self-selection treatment effect model to examine the moderating role of group affiliation on the inside shareholding-performance relationship in the following ways:

$$
y_{i t}=\alpha_{0}+\beta_{1} D_{i t}+\beta_{2} x_{i t}+\varepsilon_{i t},
$$

where is the performance measure, e.g., excess value for firm $i$ at time $t$ and $D_{i t}$ is the binary independent variable $\left(D_{i t}=1\right.$ for GAF and otherwise $D_{i t}=0$ for NGAF $i$ at time $t$ ). Xit are the control variables for a firm $i$ at time $t$ (e.g., list age, leverage, size, growth, risk \& profitability) and $\varepsilon$ it is the error term.

The group affiliation decision (selection equation) is given below:

$$
D_{i t}^{*}=\delta Z_{i t}+\mu_{i t},
$$

Dit $=1$ if $D_{i t}^{*}>0$ and $D_{i t}=0$ otherwise. $Z_{i t}$ is the variables that affect the firm's group affiliation decision; $\mu_{i t}$ is the error term.

By substituting Dit in Equation (2) with Equation (3), firm performance model is as follows:

$$
y_{i t}=\alpha_{0}+\beta_{1}\left(\delta Z_{i t}+\mu_{i t}\right)+\beta_{2} x_{i t}+\varepsilon_{i t},
$$

if $D_{i t}^{*}>0 ; D_{i t}=1$ and

$$
y_{i t}=\alpha+\beta_{2} x_{i t}+\varepsilon_{i t},
$$

where $D_{i t}^{*} \leq 0 ; D_{i t}=0$

Consistent with Heckman (1979), 2 steps method is used to find the estimates from equation $3 \& 4$. The propensity of group affiliation is estimated and finding the selection correction - called lambda [hazards] at the 1st step and then lambda [hazards] estimation is used in the regression model of firm performance at the $2^{\text {nd }}$ step.

\section{Variables definitions}

Excess value (EV)

This variable is constructed in 2 steps. In the $1^{\text {st }}$ step, the imputed value is calculated. Imputed value is found by multiplying GAF's sales with a median value of capital/ sales for NGAFs in the same sector. Then, excess weight 
of performance is discovered as the natural logarithm of actual value (market value of equity plus book value of total debts) to imputed value in the 2 nd step.

Group affiliation dummy1 (GR dummy 1).

Group affiliation status is determined by observing cross directorate-ships interlocking, cross-shareholdings \& pyramidal structures and social structures. It represents 1 for GAF and 0 for NGAF.

Group affiliation dummy2 (GR dummy 2).

A GAF is defined based on more restricted criteria. One is given to those firms that are the pyramidal firm of a BG and 0 for NGAFs.

List age (LIST)

It is calculated as a natural log of years since a firm is listed on the Pakistan Stock Exchange.

Leverage (LEV)

It is calculated as total debts divided by the total assets of the firm.

Size (SZ)

It represents the natural logarithm of the firm's total assets.

Growth (GRW)

The growth represents a change in sales concerning the previous year.

Risk (RSK)

Return on capital employed (ROCE) is calculated, and then its standard deviation is taken to measure the firm's risk.

Profitability (PROF)

It is defined as total assets divided by sales.

\section{Empirical results}

Table 1 shows that $18.14 \%$ of firm yearly observations fall in $0-10 \%$ inside the shareholdings category for NGAFs, whereas corresponding figures are remarkably higher, e.g., $29.68 \%$ for GAFs. These statistics show that insiders enjoy ultimate control with least inside shareholdings in about one-third of GAFs. The figures are significantly higher for
Table 1. Number of firm yearly observations across different categories of inside ownership for NGAFs and GAFs

\begin{tabular}{|c|c|c|c|c|}
\hline \multirow{2}{*}{ Category } & \multicolumn{2}{|c|}{ NGAF } & \multicolumn{2}{c|}{ GAF } \\
\cline { 2 - 5 } & $\begin{array}{c}\text { No. of } \\
\text { Obser- } \\
\text { vations }\end{array}$ & $\%$ & $\begin{array}{c}\text { No. of } \\
\text { Obser- } \\
\text { vations }\end{array}$ & $\%$ \\
\hline IS 0-10\% & 80 & 18.14059 & 252 & 29.68198 \\
\hline IS 10-40\% & 128 & 29.02494 & 273 & 32.15548 \\
\hline IS > 40\% & 233 & 52.83447 & 324 & 38.16254 \\
\hline $\begin{array}{c}\text { No. of } \\
\text { observations }\end{array}$ & 441 & 100 & 849 & 100 \\
\hline
\end{tabular}

NGAFs, e.g., 52.83\% than GAFs, e.g., 38.16\% when insiders' shareholding is above $40 \%$. These figures demonstrate that insiders' shareholding is more than $40 \%$ in about onehalf of the NGAFs. It postulates that the entrenchment effect may be more visible in NGAFs in Pakistan. ${ }^{* * *},{ }^{* *}$ $\&{ }^{*}$ denote significance of coefficients at $1,5 \& 10$ percent level.

The results in Panel A of Table 2 depict that GAFs' excess value was far below NGAFs for $0-10 \%$. The statistics in Panel B of Table 2 show that higher performance is demonstrated at a moderate level of inside shareholdings for NGAFs and GAFs. However, the worst performance is observed for $0-10 \%$ in GAFs. Contrarily, the lowest excess values are found for the above $40 \%$ category in NGAFs.

Table 3 shows the regression results of treatment effect models. The IS coefficient is insignificant in Model 1, whereas it is highly significant with the coefficient value of -0.05008 in Model 2. The results propose that insiders' shareholding is negatively related to firms' value in Pakistan. These results support to entrenchment effect. Firms face serious agency problems among dominant insiders and minority shareholders because these insiders make inefficient and sub-optimal decisions in a manner that benefit them personally.

Table 2. Comparison of inside shareholdings and excess values

\begin{tabular}{|c|c|c|c|c|c|c|}
\hline \multicolumn{7}{|c|}{ Panel A: Comparison of excess weight for different categories of inside shareholdings across NGAFs and GAFs } \\
\hline \multirow{2}{*}{ Category } & \multicolumn{3}{|c|}{ Mean } & \multicolumn{3}{|c|}{ Median } \\
\hline & NGAF & GAF & All & NGAF & GAF & All \\
\hline IS $0-10 \%$ & -0.02121 & $-0.13793^{\star * *}$ & -0.1098 & -0.04532 & $-0.15036^{\star * *}$ & -0.10570 \\
\hline IS $10-40 \%$ & -0.01243 & $-0.05654^{*}$ & -0.0425 & -0.00095 & $-0.07257^{\star}$ & -0.04230 \\
\hline IS > $40 \%$ & -0.08233 & -0.0909 & -0.0873 & -0.09700 & -0.11252 & -0.10470 \\
\hline \multicolumn{7}{|c|}{ Panel B: Comparison of excess values across different categories of inside shareholdings for NGAFs and GAFs } \\
\hline \multirow[t]{2}{*}{ Category } & \multicolumn{2}{|c|}{ NGAF } & & \multicolumn{2}{|c|}{ GAF } & \\
\hline & Mean & Median & & Mean & Median & \\
\hline IS $0-10 \%$ & -0.02121 & -0.04532 & & -0.13793 & -0.15036 & \\
\hline IS $10-40 \%$ & -0.01243 & -0.00095 & & -0.05654 & -0.07257 & \\
\hline IS $>40 \%$ & -0.08233 & -0.09700 & & -0.09090 & -0.11252 & \\
\hline All & $-0.05095^{\star * *}$ & $-0.05446^{* * *}$ & & $-0.09381^{\star * *}$ & $-0.10789^{\star * *}$ & \\
\hline
\end{tabular}


Consequently, minority shareholders discount share price that harms the firm's value (Khan \& Nouman, 2017; Shah et al., 2011). LIST, SZ, RSK and PROF variables show a positive relationship and GRW variable shows a negative association with firms' excess value. Both GR dummy 1 \& GR dummy two are negatively related to surplus-value. The results suggest that group affiliation harms firms' value in Pakistan. These results support earlier studies, such as Gohar and Karacaer (2009), Waseemullah and Hasan (2018). GAFs fall into agency problems as insiders is involved in tunnelling firms' wealth for private benefits at minority shareholders' expense.

Table 4 shows regression analyses demonstrating the moderating role of group affiliation in an inside shareholding-performance relationship. The IS variable is significantly negative with coefficient value of -0.08271 , whereas GR dummy $1 \mathrm{x}$ IS is incredibly affirmative with a coefficient value of 0.13407 . The interactive results suggest that insiders' ownership shows a negative relationship with NGAFs' excess-value and contrarily, it shows a positive relationship with GAF's value. The structure of BGs enables the insiders controlling firms with the least inside shareholdings that motivate them to involve in tunnelling the firm's resources to themselves. Higher the insiders' shareholdings lesser the insiders' tunnelling potential because tunnelling may be harmful to them. Insiders' incentive alignment is a useful monitoring tool that escapes minority shareholders from insiders' exploitation - the adverse performance effects of inside shareholdings for NGAFs support entrenchment effect. For the robustness of the results, interaction analyses are done using GR dummy 2. The above results are confirmed, as shown in reported figures presented in Model 2.

Table 3. Inside shareholding and firm performance

\begin{tabular}{|c|c|c|}
\hline Variable & Model 1 & Model 2 \\
\hline IS & $\begin{array}{c}0.01019 \\
(0.733)\end{array}$ & $\begin{array}{c}-0.05008^{*} \\
(0.069)\end{array}$ \\
\hline LIST & $\begin{array}{c}0.00253^{* * *} \\
(0.002)\end{array}$ & $\begin{array}{c}0.00177^{\star * *} \\
(0.001)\end{array}$ \\
\hline LEV & $\begin{array}{c}0.16629^{* * *} \\
(0.000)\end{array}$ & $\begin{array}{c}0.18107^{* * *} \\
(0.000)\end{array}$ \\
\hline $\mathrm{SZ}$ & $\begin{array}{c}0.01970^{* *} \\
(0.018)\end{array}$ & $\begin{array}{c}0.01575^{* * *} \\
(0.001)\end{array}$ \\
\hline GRW & $\begin{array}{c}-0.05113^{* * *} \\
(0.007)\end{array}$ & $\begin{array}{c}-0.05516^{* * *} \\
(0.003)\end{array}$ \\
\hline RSK & $\begin{array}{c}0.04418^{\star * *} \\
(0.005)\end{array}$ & $\begin{array}{c}0.04150^{* * *} \\
(0.007)\end{array}$ \\
\hline PROF & $\begin{array}{c}0.02501^{\star * *} \\
(0.000)\end{array}$ & $\begin{array}{c}0.02693^{\star * *} \\
(0.000)\end{array}$ \\
\hline GR dummy 1 & $\begin{array}{c}-0.09133 \\
(0.316)\end{array}$ & \\
\hline \multicolumn{2}{|c|}{ GR dummy 2} & $\begin{array}{c}-0.21493^{\star * *} \\
(0.000)\end{array}$ \\
\hline Intercept & $\begin{array}{c}-0.38486^{* * *} \\
(0.000)\end{array}$ & $\begin{array}{c}-0.36477^{\star \star *} \\
(0.000)\end{array}$ \\
\hline
\end{tabular}

End of Table 3

\begin{tabular}{|c|c|c|}
\hline Variable & Model 1 & Model 2 \\
\hline \multicolumn{3}{|c|}{ GR dummy as the dependent variable: } \\
\hline IS & $\begin{array}{c}-0.63447^{\star * *} \\
(0.000)\end{array}$ & $\begin{array}{c}-5.10582^{\star * *} \\
(0.000)\end{array}$ \\
\hline LIST & $\begin{array}{c}0.02075^{\star * *} \\
(0.000)\end{array}$ & $\begin{array}{c}-0.00379 \\
(0.437)\end{array}$ \\
\hline LEV & $\begin{array}{c}-0.16553^{\star} \\
(0.067)\end{array}$ & $\begin{array}{c}0.26724^{\star *} \\
(0.014)\end{array}$ \\
\hline SZ & $\begin{array}{c}0.23769^{* * *} \\
(0.000)\end{array}$ & $\begin{array}{c}0.08805^{\star *} \\
(0.026)\end{array}$ \\
\hline GRW & $\begin{array}{c}0.15970 \\
(0.159)\end{array}$ & $\begin{array}{c}-0.03524 \\
(0.839)\end{array}$ \\
\hline RSK & $\begin{array}{c}-0.12407 \\
(0.168)\end{array}$ & $\begin{array}{c}-0.14873 \\
(0.258)\end{array}$ \\
\hline PROF & $\begin{array}{c}0.01009 \\
(0.524)\end{array}$ & $\begin{array}{c}0.06731^{\star * *} \\
(0.001)\end{array}$ \\
\hline Intercept & $\begin{array}{c}-1.57477^{\star * *} \\
(0.000)\end{array}$ & $\begin{array}{c}-1.27578^{\star * *} \\
(0.001)\end{array}$ \\
\hline Athrho & $\begin{array}{c}0.11189 \\
(0.652)\end{array}$ & $\begin{array}{c}0.46289^{\star * *} \\
(0.000)\end{array}$ \\
\hline Lnsigma & $\begin{array}{c}-1.51134^{\star * *} \\
(0.000)\end{array}$ & $\begin{array}{c}-1.49255^{\star * *} \\
(0.000)\end{array}$ \\
\hline Wald Chi-squared & $\begin{array}{c}293.26000^{* * *} \\
(0.000)\end{array}$ & $\begin{array}{c}309.77000^{* * *} \\
(0.000)\end{array}$ \\
\hline Rho & 0.11143 & 0.43244 \\
\hline Sigma & 0.22061 & 0.22480 \\
\hline Lambda & 0.02458 & 0.09721 \\
\hline $\begin{array}{l}\text { Wald test of } \\
\text { Raho }=0\end{array}$ & $\begin{array}{c}0.16000 \\
(0.689)\end{array}$ & $\begin{array}{c}13.93000^{* * *} \\
(0.000)\end{array}$ \\
\hline
\end{tabular}

Table 4. Interaction analyses: Inside shareholdings, group affiliation and firm performance

\begin{tabular}{|c|c|c|}
\hline Variable & Model 1 & Model 2 \\
\hline IS & $\begin{array}{c}-0.08271^{\star} \\
(0.055)\end{array}$ & $\begin{array}{c}-0.04713^{\star} \\
(0.104)\end{array}$ \\
\hline LIST & $\begin{array}{c}0.00269^{* * *} \\
(0.000)\end{array}$ & $\begin{array}{c}0.00177^{\star * *} \\
(0.001)\end{array}$ \\
\hline LEV & $\begin{array}{c}0.16181^{\star * *} \\
(0.000)\end{array}$ & $\begin{array}{c}0.17310^{* * *} \\
(0.000)\end{array}$ \\
\hline SZ & $\begin{array}{c}0.02350^{\star * *} \\
(0.002)\end{array}$ & $\begin{array}{c}0.01506^{* * *} \\
(0.001)\end{array}$ \\
\hline GRW & $\begin{array}{c}-0.04884^{* * *} \\
(0.010)\end{array}$ & $\begin{array}{c}-0.05636^{* * *} \\
(0.002)\end{array}$ \\
\hline RSK & $\begin{array}{c}0.03977^{\star \star} \\
(0.011)\end{array}$ & $\begin{array}{c}0.03767^{* *} \\
(0.013)\end{array}$ \\
\hline PROF & $\begin{array}{c}0.02513^{\star * *} \\
(0.000)\end{array}$ & $\begin{array}{c}0.02611^{* * *} \\
(0.000)\end{array}$ \\
\hline GR dummy 1 & $\begin{array}{c}-0.17678^{\star *} \\
(0.031)\end{array}$ & \\
\hline \multicolumn{2}{|c|}{ GR dummy 2} & $\begin{array}{c}-0.24193^{\star * *} \\
(0.000)\end{array}$ \\
\hline GR dummy $1 \times$ IS & $\begin{array}{c}0.13407^{* * *} \\
(0.005)\end{array}$ & \\
\hline \multicolumn{2}{|c|}{ GR dummy $2 \times$ IS } & $\begin{array}{l}1.01071^{\star * *} \\
(0.000)\end{array}$ \\
\hline
\end{tabular}


End of Table 4

\begin{tabular}{|c|c|c|}
\hline Variable & Model 1 & Model 2 \\
\hline Intercept & $-0.35430^{* * *}$ & $-0.35682^{\star * *}$ \\
& $(0.000)$ & $(0.000)$ \\
\hline
\end{tabular}

GR dummy as the dependent variable:

\begin{tabular}{|c|c|c|}
\hline \multirow{2}{*}{ IS } & $\begin{array}{c}-0.63452^{\star * *} \\
(0.000)\end{array}$ & $\begin{array}{c}-4.74186^{* * *} \\
(0.000)\end{array}$ \\
\hline \multirow{2}{*}{ LIST } & $\begin{array}{c}0.02092^{\star * *} \\
(0.000)\end{array}$ & $\begin{array}{c}-0.00338 \\
(0.492)\end{array}$ \\
\hline \multirow{2}{*}{ LEV } & $-\begin{array}{c}0.16287^{\star} \\
(0.075)\end{array}$ & $\begin{array}{c}0.27118^{\star *} \\
(0.013)\end{array}$ \\
\hline
\end{tabular}

\begin{tabular}{|c|c|c|} 
& $(0.075)$ & $(0.013)$ \\
\hline \multirow{2}{*}{$S Z$} & $0.23901^{\star * \star}$ & $0.08764^{\star *}$ \\
& $(0.000)$ & $(0.0280)$ \\
\hline & 0.16214 & -0.01968
\end{tabular}

\begin{tabular}{|c|c|c|}
\hline GRW & $\begin{array}{c}0.16214 \\
(0.154)\end{array}$ & $\begin{array}{c}-0.01968 \\
(0.910)\end{array}$ \\
\hline \multirow{2}{*}{ RSK } & $\begin{array}{c}-0.12349 \\
(0.173)\end{array}$ & $\begin{array}{c}-0.13321 \\
(0.295)\end{array}$ \\
\hline \multirow{2}{*}{ PROF } & $\begin{array}{c}0.01080 \\
(0.478)\end{array}$ & $\begin{array}{c}0.06408^{* * *} \\
(0.001)\end{array}$ \\
\hline Intercept & $-1.59223^{\star * *}$ & $-1.30774^{* * *}$ \\
& $(0.000)$ & $(0.000)$ \\
\hline Athrho & $\begin{array}{c}0.20511 \\
(0.0332)\end{array}$ & $\begin{array}{c}0.33974^{* *} \\
(0.013)\end{array}$ \\
\hline Lnsigma & $-1.50625^{\star * *}$ & $-1.51180^{* * *}$ \\
& $(0.000)$ & $(0.000)$ \\
\hline Wald Chi-squared & $298.70000^{* * *}$ & $336.38000^{\star * *}$ \\
& $(0.000)$ & $(0.000)$ \\
\hline Rho & 0.20228 & 0.32725 \\
\hline Sigma & 0.22174 & 0.22051 \\
\hline Lambda & 0.04485 & 0.07216 \\
\hline Wald test of & 0.72000 & $4.25000^{* *}$ \\
|Raho $=0$ & $(0.395)$ & $(0.039)$ \\
\hline
\end{tabular}

Table 5. Inside shareholdings at different levels and firm performance

\begin{tabular}{|c|c|c|c|}
\hline Variable & Model & Model & Model \\
\hline GR dummy 1 & $\begin{array}{c}-0.11872^{*} \\
(0.101)\end{array}$ & $\begin{array}{c}-0.15061^{\star *} \\
(0.048)\end{array}$ & $\begin{array}{c}-0.09513 \\
(0.332)\end{array}$ \\
\hline IS $0-10 \%$ & $\begin{array}{c}-0.04469^{* * *} \\
(0.005)\end{array}$ & & \\
\hline IS $10-40 \%$ & & $\begin{array}{c}0.06151^{\star * *} \\
(0.000)\end{array}$ & \\
\hline IS $>40 \%$ & & & $\begin{array}{c}-0.01605 \\
(0.338)\end{array}$ \\
\hline LIST & $\begin{array}{c}0.00271^{* * *} \\
(0.000)\end{array}$ & $\begin{array}{c}0.00292^{\star * *} \\
(0.000)\end{array}$ & $\begin{array}{c}0.00256^{* * *} \\
(0.002)\end{array}$ \\
\hline LEV & $\begin{array}{c}0.16576^{* * *} \\
(0.000)\end{array}$ & $\begin{array}{c}0.16379^{* * *} \\
(0.000)\end{array}$ & $\begin{array}{c}0.16579^{* * *} \\
(0.000)\end{array}$ \\
\hline SZ & $\begin{array}{c}0.02374^{\star * *} \\
(0.001)\end{array}$ & $\begin{array}{c}0.02467^{\star * *} \\
(0.002)\end{array}$ & $\begin{array}{c}0.01910^{\star *} \\
(0.031)\end{array}$ \\
\hline GRW & $\begin{array}{c}-0.05049^{\star * *} \\
(0.008)\end{array}$ & $\begin{array}{c}-0.04820^{* \star} \\
(0.011)\end{array}$ & $\begin{array}{c}-0.05054^{\star * *} \\
(0.008)\end{array}$ \\
\hline RSK & $\begin{array}{c}0.04409^{* * *} \\
(0.004)\end{array}$ & $\begin{array}{c}0.03917^{\star *} \\
(0.011)\end{array}$ & $\begin{array}{c}0.04258^{\star * *} \\
(0.007)\end{array}$ \\
\hline PROF & $\begin{array}{c}0.02528^{* * *} \\
(0.000)\end{array}$ & $\begin{array}{c}0.02542^{* * *} \\
(0.000)\end{array}$ & $\begin{array}{c}0.02500^{* * *} \\
(0.000)\end{array}$ \\
\hline
\end{tabular}

End of Table 5

\begin{tabular}{|c|c|c|c|}
\hline Variable & Model & Model & Model \\
\hline Intercept & $\begin{array}{c}-0.38730^{* * *} \\
(0.000)\end{array}$ & $\begin{array}{c}-0.40777^{* * *} \\
(0.000)\end{array}$ & $\begin{array}{c}-0.36741^{\star * *} \\
(0.000)\end{array}$ \\
\hline \multicolumn{4}{|c|}{ GR dummy as dependent variable: } \\
\hline IS $0-10 \%$ & $\begin{array}{c}0.33884^{* * *} \\
(0.000)\end{array}$ & & \\
\hline IS $10-40 \%$ & & $\begin{array}{c}0.09862 \\
(0.224)\end{array}$ & \\
\hline IS > 40\% & & & $\begin{array}{c}-0.33343^{\star * *} \\
(0.000)\end{array}$ \\
\hline LIST & $\begin{array}{c}0.02097^{\star * *} \\
(0.000)\end{array}$ & $\begin{array}{c}0.02075^{\star * \star} \\
(0.000)\end{array}$ & $\begin{array}{c}0.02045^{\star \star *} \\
(0.000)\end{array}$ \\
\hline LEV & $\begin{array}{c}-0.16743^{\star} \\
(0.067)\end{array}$ & $\begin{array}{c}-0.15572^{\star} \\
(0.092)\end{array}$ & $\begin{array}{c}-0.15876^{\star} \\
(0.080)\end{array}$ \\
\hline SZ & $\begin{array}{c}0.23852^{* * *} \\
(0.000)\end{array}$ & $\begin{array}{l}0.24973^{* * *} \\
(0.000)\end{array}$ & $\begin{array}{l}0.24018^{* * *} \\
(0.000)\end{array}$ \\
\hline GRW & $\begin{array}{c}0.15825 \\
(0.163) \\
\end{array}$ & $\begin{array}{c}0.15134 \\
(0.184)\end{array}$ & $\begin{array}{c}0.15571 \\
(0.170)\end{array}$ \\
\hline RSK & $\begin{array}{c}-0.11310 \\
(0.213)\end{array}$ & $\begin{array}{c}-0.10253 \\
(0.262)\end{array}$ & $\begin{array}{c}-0.12518 \\
(0.167)\end{array}$ \\
\hline PROF & $\begin{array}{c}0.00983 \\
(0.518)\end{array}$ & $\begin{array}{c}0.01344 \\
(0.374)\end{array}$ & $\begin{array}{c}0.01063 \\
(0.500)\end{array}$ \\
\hline Intercept & $\begin{array}{c}-1.89965^{\star * \star} \\
(0.000)\end{array}$ & $\begin{array}{c}-1.94414^{* * *} \\
(0.000)\end{array}$ & $\begin{array}{c}-1.67333^{* * *} \\
(0.000)\end{array}$ \\
\hline Athrho & $\begin{array}{c}0.19839 \\
(0.316)\end{array}$ & $\begin{array}{c}0.26742 \\
(0.203)\end{array}$ & $\begin{array}{c}0.11408 \\
(0.669) \\
\end{array}$ \\
\hline Lnsigma & $\begin{array}{c}-1.50909^{\star * *} \\
(0.000)\end{array}$ & $\begin{array}{c}-1.50271^{\star * *} \\
(0.000)\end{array}$ & $\begin{array}{c}-1.51125^{\star * *} \\
(0.000)\end{array}$ \\
\hline $\begin{array}{l}\text { Wald Chi- } \\
\text { squared }\end{array}$ & $\begin{array}{c}307.91000^{* * *} \\
(0.000)\end{array}$ & $\begin{array}{c}306.77000^{* * *} \\
(0.000)\end{array}$ & $\begin{array}{c}291.62000^{\star * *} \\
(0.000)\end{array}$ \\
\hline Rho & 0.19582 & 0.26122 & 0.11359 \\
\hline Sigma & 0.22111 & 0.22253 & 0.22063 \\
\hline Lambda & 0.04330 & 0.05813 & 0.02506 \\
\hline $\begin{array}{l}\text { Wald test of } \\
\text { Raho }=0\end{array}$ & $\begin{array}{c}0.79000^{* * *} \\
(0.373)\end{array}$ & $\begin{array}{c}1.16000 \\
(0.28150)\end{array}$ & $\begin{array}{c}0.14000 \\
(0.708)\end{array}$ \\
\hline
\end{tabular}

The findings reported in Table 5 confirm an inverted $\mathrm{U}$ shape (negative-positive-negative) relationship between inside shareholdings and firm' value in Pakistan. The results show that the coefficient of IS $0-10 \%$ is significantly negative, depicting that inside shareholding at lower levels harm firms' value. The insiders lack incentive alignment and seem not useful in firms' monitoring. However, the coefficient of IS $10-40 \%$ is significantly positive consistent with incentives effect. These results suggest that insiders' incentives are aligned with minority shareholders when they also own a large block of shareholdings in the firms. These insiders are seriously concerned with the firm's performance and are highly motivated to monitor its activities because a significant portion of its profits or losses is distributed. The coefficient of IS $>40 \%$ shows a negative relationship with excess value. These findings support to entrenchment effect. The dominant insiders have exclusive control over the firm due to a large stake of shareholdings and face no threat from being removed from the board. They are fully entrenched and may influence the firm's 
decisions to maximise their benefits that deter firm value (Belghitar et al., 2011; Wellalage \& Locke, 2014). For the results' robustness, all three regression models are run along with group affiliation dummy 2 . The results remain unchanged and however, IS $>40 \%$ is also significantly negative. Results of studies are yet not reported to maintain conciseness.

The interactive analyses' results in Table 6 demonstrate that the IS $0-10 \%$ coefficient is insignificant, whereas GR dummy $1 \times$ IS $0-10 \%$ is significantly negatively related to excess value. The results indicate that inside shareholding at lower levels is not connected with NGAFs' performance. Contrarily, it strongly negatively associated with GAFs' profitability. The findings confirm the descriptive statistics' results presented above. The group structure enables the insiders to connect and maintain ultimate control over GAFs' with least shareholdings through cross-shareholdings' interlocking. This kind of shareholdings pattern motivates the GAFs' insiders extract private benefits in a manner that costs to minority shareholders. The findings support the divergence of interest effects (Claessens et al., 1999; Laeven \& Levine, 2007; Bertrand et al., 2002; Chang, 2003; Martin et al., 2017).

The coefficient of IS $10-40 \%$ is positive and highly significant at $1 \%$ whereas GR dummy coefficient $1 \times$ IS $10-40 \%$ is not substantial. The results propose that inside shareholdings at medium levels show a positive association with NGAF's excess value. However, it does not offer a considerable difference in a relationship for GAFs. Further, the IS $>40 \%$ coefficient is negative, and GR dummy $1 \times$ IS $>40 \%$ is significantly positive. These findings reveal those inside shareholdings at higher levels inversely affect NGAFs' value consistent with entrenchment effect and however, opposite relation is valid for GAFs. The insiders with large stakes of shareholdings exert entrenched behaviour to enjoy personal benefits harmful to NGAF's value (Bozec \& Laurin, 2008). We also apply the robustness check. Thus, interactive analyses are done by using Group affiliation dummy 2. The above results are confirmed. However, the interaction between group affiliation and IS $10-40 \%$ is significantly positive as well.

Table 6. Interactive analyses: Inside shareholdings at different levels, group affiliation and firm performance

\begin{tabular}{|c|c|c|c|}
\hline Variable & Model 1 & Model 2 & Model 3 \\
\hline GR dummy 1 & $\begin{array}{c}-0.12260^{*} \\
(0.071)\end{array}$ & $\begin{array}{c}-0.15006^{\star *} \\
(0.048)\end{array}$ & $\begin{array}{c}-0.15494^{\star} \\
(0.074)\end{array}$ \\
\hline IS $0-10 \%$ & $\begin{array}{c}0.00707 \\
(0.807)\end{array}$ & & \\
\hline IS $10-40 \%$ & & $\begin{array}{c}0.06443^{* * *} \\
(0.006)\end{array}$ & \\
\hline IS $>40 \%$ & & & $\begin{array}{c}-0.05661^{\star *} \\
(0.020)\end{array}$ \\
\hline LIST & $\begin{array}{c}0.00286^{* * *} \\
(0.000)\end{array}$ & $\begin{array}{c}0.00292^{* * *} \\
(0.000)\end{array}$ & $\begin{array}{c}0.00271^{\star * *} \\
(0.000)\end{array}$ \\
\hline
\end{tabular}

End of Table 6

\begin{tabular}{|c|c|c|c|}
\hline Variable & Model 1 & Model 2 & Model 3 \\
\hline LEV & $\begin{array}{c}0.16229^{* * *} \\
(0.000)\end{array}$ & $\begin{array}{c}0.16383^{* * *} \\
(0.000)\end{array}$ & $\begin{array}{c}0.16324^{* * *} \\
(0.000)\end{array}$ \\
\hline SZ & $\begin{array}{c}0.02564^{* * *} \\
(0.000)\end{array}$ & $\begin{array}{c}0.02473^{\star * *} \\
(0.001)\end{array}$ & $\begin{array}{c}0.02221^{\star * *} \\
(0.006)\end{array}$ \\
\hline GRW & $\begin{array}{c}-0.04895^{\star * *} \\
(0.010)\end{array}$ & $\begin{array}{c}-0.04818^{\star *} \\
(0.011)\end{array}$ & $\begin{array}{c}-0.04870^{* *} \\
(0.011)\end{array}$ \\
\hline RSK & $\begin{array}{c}0.04198^{* * *} \\
(0.006)\end{array}$ & $\begin{array}{c}0.03907^{\star *} \\
(0.011)\end{array}$ & $\begin{array}{c}0.03935^{\star *} \\
(0.012)\end{array}$ \\
\hline PROF & $\begin{array}{c}0.02523^{\star * *} \\
(0.000)\end{array}$ & $\begin{array}{c}0.02542^{\star * *} \\
(0.000)\end{array}$ & $\begin{array}{c}0.02509^{* * *} \\
(0.000)\end{array}$ \\
\hline $\begin{array}{c}\text { GR dummy } \\
1 \times \text { IS } 0-10 \%\end{array}$ & $\begin{array}{c}-0.06847^{\star *} \\
(0.032)\end{array}$ & & \\
\hline \multicolumn{2}{|c|}{ GR dummy $1 \times$ IS $10-40 \%$} & $\begin{array}{c}-0.00430 \\
(0.878) \\
\end{array}$ & \\
\hline \multicolumn{2}{|c|}{ GR dummy $1 \times$ IS > 40\% } & & $\begin{array}{c}0.05717^{\star *} \\
(0.031)\end{array}$ \\
\hline Intercept & $\begin{array}{c}-0.40037^{* * *} \\
(0.000)\end{array}$ & $\begin{array}{c}-0.40862^{* * *} \\
(0.000)\end{array}$ & $\begin{array}{c}-0.35070^{\star * *} \\
(0.000)\end{array}$ \\
\hline
\end{tabular}

GR dummy as dependent variable:

\begin{tabular}{|c|c|c|c|}
\hline IS $0-10 \%$ & $\begin{array}{c}0.34477^{\star * *} \\
(0.000)\end{array}$ & & \\
\hline IS $10-40 \%$ & & $\begin{array}{l}0.09896 \\
(0.223)\end{array}$ & \\
\hline IS $>40 \%$ & & & $\begin{array}{c}-0.33286^{* * *} \\
(0.000)\end{array}$ \\
\hline LIST & $\begin{array}{c}0.02104^{* * *} \\
(0.000)\end{array}$ & $\begin{array}{c}0.02076^{* * *} \\
(0.000)\end{array}$ & $\begin{array}{c}0.02060^{* * *} \\
(0.000)\end{array}$ \\
\hline LEV & $\begin{array}{c}-0.16698^{*} \\
(0.070)\end{array}$ & $\begin{array}{c}-0.15575^{*} \\
(0.092)\end{array}$ & $\begin{array}{c}-0.15649^{*} \\
(0.087)\end{array}$ \\
\hline SZ & $\begin{array}{c}0.23899^{* * *} \\
(0.000)\end{array}$ & $\begin{array}{c}0.24974^{\star * *} \\
(0.000)\end{array}$ & $\begin{array}{l}0.24121^{* * *} \\
(0.000)\end{array}$ \\
\hline GRW & $\begin{array}{c}0.15949 \\
(0.161)\end{array}$ & $\begin{array}{c}0.15140 \\
(0.184)\end{array}$ & $\begin{array}{c}0.15798 \\
(0.165)\end{array}$ \\
\hline RSK & $\begin{array}{c}-0.11222 \\
(0.219)\end{array}$ & $\begin{array}{c}-0.10256 \\
(0.262)\end{array}$ & $\begin{array}{c}-0.12424 \\
(0.173)\end{array}$ \\
\hline PROF & $\begin{array}{c}0.01046 \\
(0.485)\end{array}$ & $\begin{array}{c}0.01348 \\
(0.373)\end{array}$ & $\begin{array}{c}0.01147 \\
(0.452)\end{array}$ \\
\hline Intercept & $\begin{array}{c}-1.90769^{* * *} \\
(0.000)\end{array}$ & $\begin{array}{c}-1.94451^{* * *} \\
(0.000)\end{array}$ & $\begin{array}{c}-1.68866^{* * *} \\
(0.000)\end{array}$ \\
\hline Athrho & $\begin{array}{c}0.24795 \\
(0.186)\end{array}$ & $\begin{array}{c}0.26962 \\
(0.199)\end{array}$ & $\begin{array}{c}0.20345 \\
(0.374)\end{array}$ \\
\hline Lnsigma & $\begin{array}{c}-1.50483^{* * *} \\
(0.000)\end{array}$ & $\begin{array}{c}-1.50240^{\star * *} \\
(0.000)\end{array}$ & $\begin{array}{c}-1.50529^{* * *} \\
(0.000)\end{array}$ \\
\hline $\begin{array}{l}\text { Wald Chi- } \\
\text { squared }\end{array}$ & $\begin{array}{c}310.34000^{* * *} \\
(0.000)\end{array}$ & $\begin{array}{c}306.62000^{* * *} \\
(0.000)\end{array}$ & $\begin{array}{c}293.33000^{* * *} \\
(0.000)\end{array}$ \\
\hline Rho & 0.24299 & 0.26327 & 0.20069 \\
\hline Sigma & 0.22206 & 0.22260 & 0.22195 \\
\hline Lambda & 0.05396 & 0.05860 & 0.04454 \\
\hline $\begin{array}{c}\text { Wald test of } \\
\text { Raho }=0\end{array}$ & $\begin{array}{l}1.35000 \\
(0.245)\end{array}$ & $\begin{array}{l}1.18000 \\
(0.278)\end{array}$ & $\begin{array}{c}0.59000 \\
(0.443)\end{array}$ \\
\hline
\end{tabular}


Table 7. Non-linearity of inside shareholdings and firm performance

\begin{tabular}{|c|c|c|}
\hline Variable & Model 1 & Model 2 \\
\hline IS & $\begin{array}{c}0.64794^{* * *} \\
(0.000)\end{array}$ & $\begin{array}{c}0.34330^{*} \\
(0.065)\end{array}$ \\
\hline ISSQUARE & $\begin{array}{c}-1.74933^{\star * *} \\
(0.000)\end{array}$ & $\begin{array}{c}-1.22994^{* *} \\
(0.014)\end{array}$ \\
\hline ISCUBE & $\begin{array}{l}1.22231^{* * *} \\
(0.001)\end{array}$ & $\begin{array}{l}0.95918^{\star * *} \\
(0.010)\end{array}$ \\
\hline LIST & $\begin{array}{c}0.00251^{* * *} \\
(0.001)\end{array}$ & $\begin{array}{c}0.00172^{* * *} \\
(0.001)\end{array}$ \\
\hline LEV & $\begin{array}{c}0.16730^{\star * *} \\
(0.000)\end{array}$ & $\begin{array}{c}0.18107^{\star * *} \\
(0.000)\end{array}$ \\
\hline SZ & $\begin{array}{c}0.02107^{* * *} \\
(0.008)\end{array}$ & $\begin{array}{c}0.01562^{* * *} \\
(0.001)\end{array}$ \\
\hline GRW & $\begin{array}{c}-0.05005^{\star * \star} \\
(0.008)\end{array}$ & $\begin{array}{c}-0.05494^{* * *} \\
(0.003)\end{array}$ \\
\hline RSK & $\begin{array}{c}0.04408^{* * *} \\
(0.004)\end{array}$ & $\begin{array}{c}0.04217^{\star * *} \\
(0.006)\end{array}$ \\
\hline PROF & $\begin{array}{c}0.02532^{* * *} \\
(0.000)\end{array}$ & $\begin{array}{c}0.02685^{\star * *} \\
(0.000)\end{array}$ \\
\hline GR dummy 1 & $\begin{array}{c}-0.10120 \\
(0.233)\end{array}$ & \\
\hline \multicolumn{2}{|c|}{ GR dummy 2} & $\begin{array}{c}-0.20046^{* * *} \\
(0.000)\end{array}$ \\
\hline Intercept & $\begin{array}{c}-0.42466^{\star * *} \\
(0.000)\end{array}$ & $\begin{array}{c}-0.38217^{* * *} \\
(0.000)\end{array}$ \\
\hline \multicolumn{3}{|c|}{ GR dummy as the dependent variable: } \\
\hline IS & $\begin{array}{c}-0.63372^{* * *} \\
(0.000)\end{array}$ & $\begin{array}{c}-4.93515^{* * *} \\
(0.000)\end{array}$ \\
\hline LIST & $0.02081^{\star * *}(0.000)$ & $\begin{array}{c}-0.00369 \\
(0.450)\end{array}$ \\
\hline LEV & $-0.16466^{\star}(0.070)$ & $\begin{array}{c}0.26755^{\star *} \\
(0.014)\end{array}$ \\
\hline SZ & $0.23822^{\star * *}(0.000)$ & $\begin{array}{c}0.08720^{\star *} \\
(0.028)\end{array}$ \\
\hline GRW & $0.16048(0.157)$ & $\begin{array}{c}-0.03229 \\
(0.852)\end{array}$ \\
\hline RSK & $-0.12415(0.168)$ & $\begin{array}{c}-0.14992 \\
(0.254)\end{array}$ \\
\hline PROF & $0.01020(0.513)$ & $\begin{array}{c}0.06608^{* * *} \\
(0.001)\end{array}$ \\
\hline Intercept & $\begin{array}{c}-1.58167^{* * *} \\
(0.000)\end{array}$ & $\begin{array}{c}-1.28306^{* * *} \\
(0.001)\end{array}$ \\
\hline Athrho & $0.14123(0.543)$ & $\begin{array}{c}0.43061^{\star * *} \\
(0.000)\end{array}$ \\
\hline Lnsigma & $\begin{array}{c}-1.51497^{\star * *} \\
(0.000)\end{array}$ & $\begin{array}{c}-1.49847^{\star * *} \\
(0.000)\end{array}$ \\
\hline Wald Chi-squared & $\begin{array}{c}310.28000^{* * *} \\
(0.000)\end{array}$ & $\begin{array}{c}317.41000^{* * *} \\
(0.000)\end{array}$ \\
\hline Rho & 0.14030 & 0.40583 \\
\hline Sigma & 0.21981 & 0.22347 \\
\hline Lambda & 0.03084 & 0.09069 \\
\hline $\begin{array}{l}\text { Wald test of Raho } \\
=0\end{array}$ & $0.29000(0.591)$ & $\begin{array}{c}8.68000^{* * *} \\
(0.003)\end{array}$ \\
\hline
\end{tabular}

The results in Table 7 indicate non-linear relationships between inside shareholdings and firms' value. The coefficients of IS \& ISCUBE variables are significantly positive, whereas ISSQUARE variable is incredibly harmful. The findings suggest that inside shareholdings increase firms' value when it increases at initial levels until they reach a certain level. Then, firms' value started to decrease as insiders attain substantial control over the firm. Again, firms' value started to increase when inside shareholdings increase further beyond a certain threshold level. Considerable shareholdings' stakes restrict the insiders' tunnelling potential because discount in share prices by the minority shareholders may cost them more than private gains. The findings support results of prior researches like Morck et al. (1988), De Miguel et al. (2005), Kamardin (2014), Ruan et al. (2011), Pant and Pattanayak (2007) and Hoang et al. (2017).

Table 8 reports the interactive analyses between group affiliation and inside shareholdings (IS, ISSQUARE \& ISCUBE). All of the coefficient values for interactive dummies including GR dummy $1 \mathrm{x}$ IS, GR dummy $1 \mathrm{x}$ ISSQUARE \& GR dummy $1 \mathrm{x}$ ISCUBE are positive, and results are significant at conventional levels of significance. The findings reveal that the effect of increased inside shareholdings at initial levels is affirmative for both GAFs and NGAFs; however, positive results are more robust for GAFs than NGAFs. A further increase in inside shareholdings decrease NGAFs' value, but the strength of relationships is lower for GAFs. Similarly, after that inside shareowners reach at a very high level, an increase in inside shareholdings again beyond that levels increases both GAFs and NGAFs' value. Still, the strength of the relationship is also healthier for GAFs than NGAFs. The findings reveal that inside shareholding helps GAFs mitigate agency conflicts among the insiders and minority shareholders. The results are partially consistent with Itturalde et al. (2011) and Kamardin (2014). The results remain unchanged when using GR dummy 2 (results not reported for brevity).

Table 8. Interactive analyses: Non-linearity of inside shareholdings, group affiliation and firms' value

\begin{tabular}{|c|c|c|c|}
\hline Variable & Model 1 & Model 2 & Model 3 \\
\hline GR dummy 1 & $\begin{array}{c}-0.19508^{\star *} \\
(0.014)\end{array}$ & $\begin{array}{c}-0.16251^{* *} \\
(0.040)\end{array}$ & $\begin{array}{c}-0.14489^{*} \\
(0.069)\end{array}$ \\
\hline IS & $\begin{array}{c}0.57846^{* * *} \\
(0.001)\end{array}$ & $\begin{array}{c}0.69560^{* * *} \\
(0.000)\end{array}$ & $\begin{array}{c}0.70307^{* * *} \\
(0.000)\end{array}$ \\
\hline ISSQUARE & $\begin{array}{c}-1.91007^{* * *} \\
(0.000)\end{array}$ & $\begin{array}{c}-2.06461^{* * *} \\
(0.000)\end{array}$ & $\begin{array}{c}-1.98665^{* * *} \\
(0.000)\end{array}$ \\
\hline ISCUBE & $\begin{array}{c}1.37488^{* * *} \\
(0.000)\end{array}$ & $\begin{array}{c}1.42344^{* * *} \\
(0.000)\end{array}$ & $\begin{array}{c}1.34124^{* * *} \\
(0.000)\end{array}$ \\
\hline LIST & $\begin{array}{c}0.00267^{* * *} \\
(0.000)\end{array}$ & $\begin{array}{c}0.00261^{* * *} \\
(0.000)\end{array}$ & $\begin{array}{c}0.00258^{* * *} \\
(0.000)\end{array}$ \\
\hline LEV & $\begin{array}{c}0.16233^{* * *} \\
(0.000)\end{array}$ & $\begin{array}{c}0.16333^{* * *} \\
(0.000)\end{array}$ & $\begin{array}{c}0.16409^{* * *} \\
(0.000)\end{array}$ \\
\hline SZ & $\begin{array}{c}0.02512^{* * *} \\
(0.001)\end{array}$ & $\begin{array}{c}0.02425^{* * *} \\
(0.001)\end{array}$ & $\begin{array}{c}0.02356^{* * *} \\
(0.002)\end{array}$ \\
\hline
\end{tabular}


End of Table 8

\begin{tabular}{|c|c|c|c|}
\hline Variable & Model 1 & Model 2 & Model 3 \\
\hline GRW & $\begin{array}{c}-0.04757^{\star *} \\
(0.012)\end{array}$ & $\begin{array}{c}-0.04820^{* * *} \\
(0.011)\end{array}$ & $\begin{array}{c}-0.04864^{* * *} \\
(0.010)\end{array}$ \\
\hline RSK & $\begin{array}{c}0.03924^{* *} \\
(0.011)\end{array}$ & $\begin{array}{c}0.04076^{* * *} \\
(0.008)\end{array}$ & $\begin{array}{c}0.04171^{\star * *} \\
(0.007)\end{array}$ \\
\hline PROF & $\begin{array}{c}0.02543^{* * *} \\
(0.000)\end{array}$ & $\begin{array}{c}0.02545^{\star * *} \\
(0.000)\end{array}$ & $\begin{array}{c}0.02545^{* * *} \\
(0.000)\end{array}$ \\
\hline $\begin{array}{c}\text { GR dummy } 1 \\
\times \text { IS }\end{array}$ & $\begin{array}{c}0.14954^{* * *} \\
(0.002)\end{array}$ & & \\
\hline \multicolumn{2}{|c|}{ GR dummy $1 \times$ ISSQUARE } & $\begin{array}{c}0.14940^{* * *} \\
(0.009)\end{array}$ & \\
\hline \multicolumn{2}{|c|}{ GR dummy $1 \times$ ISCUBE } & & $\begin{array}{c}0.15246^{* *} \\
(0.024)\end{array}$ \\
\hline Intercept & $\begin{array}{c}-0.38937^{* * *} \\
(0.000)\end{array}$ & $\begin{array}{c}-0.40596^{* * *} \\
(0.000)\end{array}$ & $\begin{array}{c}-0.41342^{\star * *} \\
(0.000)\end{array}$ \\
\hline \multicolumn{4}{|c|}{ GR dummy as dependent variable: } \\
\hline IS & $\begin{array}{c}-0.63620^{* * *} \\
(0.000)\end{array}$ & $\begin{array}{c}-0.63427^{* * *} \\
(0.000)\end{array}$ & $\begin{array}{c}-0.63352^{\star * *} \\
(0.000)\end{array}$ \\
\hline LIST & $\begin{array}{c}0.02100^{\star * *} \\
(0.000)\end{array}$ & $\begin{array}{c}0.02097^{\star * *} \\
(0.000)\end{array}$ & $\begin{array}{c}0.02094^{* * *} \\
(0.000)\end{array}$ \\
\hline LEV & $\begin{array}{c}-0.16254^{\star} \\
(0.077)\end{array}$ & $\begin{array}{c}-0.16264^{*} \\
(0.076)\end{array}$ & $\begin{array}{c}-0.16291^{*} \\
(0.075)\end{array}$ \\
\hline $\mathrm{SZ}$ & $\begin{array}{c}0.23943^{* * *} \\
(0.000)\end{array}$ & $\begin{array}{c}0.23916^{* * *} \\
(0.000)\end{array}$ & $\begin{array}{c}0.23895^{* * *} \\
(0.000)\end{array}$ \\
\hline GRW & $\begin{array}{l}0.16316 \\
(0.152)\end{array}$ & $\begin{array}{l}0.16250 \\
(0.153)\end{array}$ & $\begin{array}{l}0.16197 \\
(0.154)\end{array}$ \\
\hline RSK & $\begin{array}{c}-0.12368 \\
(0.173)\end{array}$ & $\begin{array}{c}-0.12398 \\
(0.171)\end{array}$ & $\begin{array}{c}-0.12408 \\
(0.170)\end{array}$ \\
\hline PROF & $\begin{array}{c}0.01125 \\
(0.455)\end{array}$ & $\begin{array}{c}0.01091 \\
(0.471)\end{array}$ & $\begin{array}{c}0.01068 \\
(0.483)\end{array}$ \\
\hline Intercept & $\begin{array}{c}-1.59788^{* * *} \\
(0.000)\end{array}$ & $\begin{array}{c}-1.59533^{\star * *} \\
(0.000)\end{array}$ & $\begin{array}{c}-1.59259^{\star * *} \\
(0.000)\end{array}$ \\
\hline Athrho & $\begin{array}{c}0.24270 \\
(0.237)\end{array}$ & $\begin{array}{c}0.21939 \\
(0.296)\end{array}$ & $\begin{array}{c}0.20055 \\
(0.349)\end{array}$ \\
\hline Lnsigma & $\begin{array}{c}-1.50804^{* * *} \\
(0.000)\end{array}$ & $\begin{array}{c}-1.50989^{* * *} \\
(0.000)\end{array}$ & $\begin{array}{c}-1.51139^{* * *} \\
(0.000)\end{array}$ \\
\hline $\begin{array}{l}\text { Wald Chi- } \\
\text { squared }\end{array}$ & $\begin{array}{c}316.34000^{* * *} \\
(0.000)\end{array}$ & $\begin{array}{c}314.60000^{* * *} \\
(0.000)\end{array}$ & $\begin{array}{c}313.66000^{* * *} \\
(0.000)\end{array}$ \\
\hline Rho & 0.23805 & 0.21594 & 0.19791 \\
\hline Sigma & 0.22134 & 0.22093 & 0.22060 \\
\hline Lambda & 0.05269 & 0.04771 & 0.04366 \\
\hline $\begin{array}{c}\text { Wald test of } \\
\text { Raho }=0\end{array}$ & $\begin{array}{l}1.06000 \\
(0.304)\end{array}$ & $\begin{array}{c}0.83000 \\
(0.361)\end{array}$ & $\begin{array}{c}0.67000 \\
(0.411)\end{array}$ \\
\hline
\end{tabular}

\section{Conclusions}

Institutional setting plays a critical role in shaping the economic landscape of the economy. Institutional infrastructure is under-developed in emerging countries, and BGs are more common in such environments because BGs are more capable of coping with institutional failures. BGs tend to decline in performance (Waseemullah \& Hasan, 2018; Gohar \& Karacaer, 2009). Agency theorists argue that BGs face severe agency conflicts (Martin et al., 2017). They are engaged in diversifying the firm's resources to themselves at minority shareholders' costs
(Laeven \& Levine, 2007; Bertrand et al., 2002). Tunnelling of resources flows from those firms where ultimate insiders (controllers) have the least cash flow rights to those firms with higher cash flow rights (Claessens et al., 2002; King \& Santor, 2008). Insiders' incentives' alignment is the most powerful tool to escape minority shareholders from the ultimate controllers in the absence of external governance system (Heugens \& Lander, 2009; Javid \& Iqbal, 2008; Filatotchev et al., 2013; Nguyen et al., 2015).

The study examines the effect of inside-shareholdings on firms' performance, the linearity of inside shareholding-performance relationships, and the performance impacts of inside shareholdings at different levels. Most importantly, the study investigates these relationships for GAFs relative to NGAFs. The results indicate that inside shareholdings negatively affect firms' value. The findings support prior studies' outcomes, such as Fahlenbrach and Stulz (2008), Shah et al. (2011). However, the effect of inside shareholding on firms' value is not similar for GAFs and NGAFs. Inside shareholding is negatively related to NGAFs' value, whereas it is positively related to GAFs' value. BGs structure motivates the insiders (ultimate controllers) controlling other firms with lesser cash flows. They use cross directorate-ship, cross-shareholdings and different ways for extending their control than cash flows rights. The insiders are motivated to extract private gains, which ultimately causes agency problems between insiders and minority shareholders. Inside shareholding is the primary monitoring tool that aligns the insiders' incentives with external shareholders and helps mitigate agency conflicts (Claessens et al., 1999; Chang, 2003).

Most importantly, inside shareholdings at various levels differently affect firms' value. The findings show negative-positive-negative relationships between inside shareholdings and firms' value. It is negatively related to firms' value at lower levels (IS 0-10\%) and higher levels (IS10-40\%) inside shareholdings consistent with divergence of interest effect and entrenchment effect. Insiders lack incentives' alignment when inside shareholdings range between $0-10 \%$ whereas they are fully entrenched when they own more than $40 \%$ of shares. Inside shareholdings on firms' value are positive only when it ranges between $10-40 \%$. Insiders converge to the interests of minority shareholders and are highly entrenched with a moderate level of shareholdings (Belghitar et al., 2011; Wellalage \& Locke, 2014). Moreover, results show an interesting trend when examining the relationship between shareholding-performance relationships for GAFs and NGAFs. The association is strongly negative for GAFs at lower levels (IS 0-10\%) whereas it is highly unfavourable for NGAFs at higher levels (IS $>40 \%$ ). The insiders of GAFs having an ultimate control with least shareholdings are not useful in the firm's monitoring. They are highly motivated to make personal gains rather than maximise firm value due to divergence of interest effect. As crossshareholdings and pyramidal structures are not prevalent in NGAFs, insiders can achieve control through inside shareholdings only. Inside shareholdings with IS $>40 \%$ are 
more visible in NGAFs and affect NGAFs' value adversely due to entrenchment effect. Divergence of interest effect is well pronounced in GAFs, whereas the entrenchment effect is more visible in NGAFs.

Lastly, findings also reveal non-linearity of inside shareholding-performance relationship in Pakistan. An increase in inside shareholding at lower level increases the firm's value as insiders' incentives started to align with external shareholders' incentives. However, after inside shareholding reaches a moderate level, a further increase may destroy the firm's value because insiders with substantial control possess both potential and incentives of tunnelling firms' resources because these cost them lower than personal benefits. Moreover, after inside shareholding reaches a higher level, a further increase in insiders' ownership does not lead them to exert entrenched behaviour because it may cost more than their private gains. However, the interaction between group affiliation and inside shareholding and square \& cube terms are favourable. It suggests that increased inside shareholdings at initial and higher levels contribute to enhanced GAFs' performance with greater strength than NGAFs. And increase in inside ownership further after it has reached a moderate level lowers firm' value but the power of the relationship is lesser for GAFs than NGAFs in Pakistan.

\section{Acknowledgements}

We are grateful to all of those with whom we have had the pleasure to work during this project. We would especially like to thank managers' family businesses, who helped us in gathering data of the research article. I wish to thank my loving and supportive wife, Farzana Rubbani, and my two wonderful sons, Azhaf and Ashnab, whom time I stole to complete this project.

\section{Author contributions}

WS conceptualized the study, contributed the data analysis and parts of the literature review. ST and SK contributed the background, parts of the literature review, and refined the draft paper. MUQ corrected grammatical mistakes and spellings. All authors read and approved the final manuscript.

\section{Disclosure statement}

There is no financial and non-financial competing interest.

\section{References}

Abdullah, F., Shah, A., Gohar, R., \& Iqbal, A. M. (2011). The effect of group and family ownership on firm performance: Empirical evidence from Pakistan. International Review of Business Research Papers, 7(4), 191-208.

https://papers.ssrn.com/sol3/papers.cfm?abstract_id=1907150

Ali, W., Ansari, R. H., \& Memon, M. A. B. (2020). Corporate governance and firm financial performance: a meta-analysis study. Journal of Accounting and Finance in Emerging Economies, 6(4), 917-940.

https://doi.org/10.26710/jafee.v6i4.1401

Ali, S. Z. A. S. S., \& Saeed, M. M. (2011). Ownership structure and performance of firms: Empirical evidence from an emerging market. African Journal of Business Management, 5(2), 515-523.

Arshad, H., \& Javid, A. Y. (2014). Does inside ownership matters in financial decisions and firm performance: Evidence from manufacturing sector of Pakistan. In PIDE-Working Papers 2014:107. Pakistan Institute of Development Economics. http://pide.org.pk

Bae, S. C., Kwon, T. H., \& Lee, J. W. (2011). Does corporate diversification by business groups create value? Evidence from Korean chaebols. Pacific-Basin Finance Journal, 19(5), 535553. https://doi.org/10.1016/j.pacfin.2011.04.001

Banchit, A., \& Locke, S. M. (2011). Principal-principal cost: Is it a Big Problem in Asean 4 Markets? International Business Research Review Papers, 2(5), 1-15. https://www.researchgate. net/publication/265236898_Principal-principal_cost_Is_it_a_ Big_Problem_in_Asean_4_Markets/citatations

Bebchuk, L. A., \& Weisbach, M. S. (2010). The state of corporate governance research. The Review of Financial Studies, 23(3), 939-961. https://doi.org/10.1093/rfs/hhp121

Belghitar, Y., Clark, E. \& Kassimatis, K. (2011). Managerial ownership and firm performance: A re-examination using marginal conditional stochastic dominance. European Financial Management Association. https://pdfs.semanticscholar.org/7552/ afa8ad14697d31581ff1fbc1ab6647c89fed.pdf

Benson, B. W., \& Davidson, W. N. (2009). Re-examining the managerial ownership effect on firm value. Journal of Corporate Finance, 15(5), 573-586.

https://doi.org/10.1016/j.jcorpfin.2009.08.002

Berger, P. G., \& Ofek, E. (1995). Diversification's effect on firm value. Journal of Financial Economics, 37(1), 39-65. https://doi.org/10.1016/0304-405X(94)00798-6

Berke-Berga, A., I. Dovladbekova, \& Abula, M. (2017). Managerial ownership and firm performance: Evidence of listed companies in the Baltics. Polish Journal of Management Studies, 15(2), 273-283. https://doi.org/10.17512/pjms.2017.15.2.25

Bertrand, M., Mehta, P., \& Mullainathan, S. (2002). Ferreting out tunneling: An application to Indian business groups. Quarterly Journal of Economics, 117(1), 121-148. https://doi.org/10.1162/003355302753399463

Bozec, Y., \& Laurin, C. (2008). Large shareholder entrenchment and performance: Empirical evidence from Canada. Journal of Business Finance \& Accounting, 35(1-2), 25-49. https://doi.org/10.1111/j.1468-5957.2007.02066.x

Chang, S. J. (2003). Ownership structure, expropriation, and performance of group-affiliated companies in Korea. Academy of Management Journal, 46(2), 238-253. https://doi.org/10.5465/30040617

Choe, C., Dey, T., \& Mishra, V. (2014). Corporate diversification, executive compensation and firm value: Evidence from Australia. Australian Journal of Management, 39, 395-414. https://doi.org/10.1177/0312896213499027

Claessens, S., Djankov, S., Fan, J. P., \& Lang, L. H. (1999). Expropriation of minority shareholders: Evidence from East Asia. World Bank Washington, DC. https://doi.org/10.1596/1813-9450-2088

Claessens, S., Djankov, S., Fan, J. P., \& Lang, L. H. (2002). Disentangling the incentive and entrenchment effects of large 
shareholdings. The Journal of Finance, 57(6), 2741-2771. https://doi.org/10.1111/1540-6261.00511

Coles, J. L., Lemmon, M. L., \& Meschke, F. (2012). Structural models and endogeneity in corporate finance: The link between managerial ownership and corporate performance. Journal of Financial Economics, 103(1), 149-168. https://doi.org/10.1016/j.jfineco.2011.04.002

De Miguel, A., Pindado, J., \& De La Torre, C. (2005). How do entrenchment and expropriation phenomena affect control mechanisms? Corporate Governance: An International Review, 13(4), 505-516.

https://doi.org/10.1111/j.1467-8683.2005.00445.x

Demsetz, H., \& Lehn, K. (1985). The structure of corporate ownership: Causes and consequences. Journal of Political Economy, 93(6), 1155-1177. https://doi.org/10.1086/261354

Djankov, S., La Porta, R., Lopez-de-Silanes, F., \& Shleifer, A. (2008). The law and economics of self-dealing. Journal of Financial Economics, 88(3), 430-65.

https://doi.org/10.1016/j.jfineco.2007.02.007

Fahlenbrach, R., \& Stulz, R. M. (2008). Managerial ownership dynamics and firm value. Journal of Financial Economics, 92(3), 342-361. https://doi.org/10.2139/ssrn.992919

Filatotchev, I., Jackson, G., \& Nakajima, C. (2013). Corporate governance and national institutions: A review and emerging research agenda. Asia Pacific Journal of Management, 30(4), 965-986. https://doi.org/10.1007/s10490-012-9293-9

Gohar, R., \& Karacaer, S. (2009). Pakistani business groups: A comparison of group affiliated and unaffiliated firm performance. NUST Journal of Business and Economics, 2(2), 41-53.

Gordon, G., \& Nicholson, N. (2010). Family wars: Stories and insights from famous family business feuds. Kogan Page. https:// www.amazon.com/Family-Wars-Stories-Insights-Businessebook/dp/B005EROETC

Hamza, S. M., \& Suman, S. S. (2018). The impact of ownership structure and firm performance: A study on Bombay Stock Exchange in India. International Journal of Accounting \& Business Management, 6(1), 21-38.

He, J., Mao, X., Rui, O. M., \& Zha, X. (2013). Business groups in China. Journal of Corporate Finance, 22, 166-192. https://doi.org/10.1016/j.jcorpfin.2013.05.001

Heckman, J. J. (1979). Sample selection bias as a specification error. Econometrica, 47(1), 153-61. https://doi.org/10.2307/1912352

Heugens, P. P., \& Lander, M. W. (2009). Structure! Agency! (and other quarrels): A meta-analysis of institutional theories of organisation. Academy of Management Journal, 52(1), 61-85. https://doi.org/10.5465/amj.2009.36461835

Hoang, L. T., Nguyen, C. C., \& Hu, B. (2017). Ownership structure and firm performance improvement: Does it matter in the Vietnamese Stock Market? Economic Papers, 36(4), 416-428. https://doi.org/10.1111/1759-3441.12185

Hu, Y., \& Zhou, X. (2008). The performance effect of managerial ownership: Evidence from China. Journal of Banking \& Finance, 32(10), 2099-2110.

https://doi.org/10.1016/j.jbankfin.2007.12.047

Itturalde, D. T., Maseda, D. A., \& Arosa, D. B. (2011). Insiders ownership and firm performance. Empirical evidence. International Research Journal of Finance and Economics, 67, 118-129.

Javid, A. Y., \& Iqbal, R. (2008). Ownership concentration, corporate governance and firm performance: Evidence from Pakistan. The Pakistan Development Review, 47(4), 643-659. https://doi.org/10.30541/v47i4IIpp.643-659
Jensen, M. C. (1986). Agency costs of free cash ow, corporate finance, and takeovers. The American Economic Review, 76(2), 323-329. https://doi.org/10.2139/ssrn.99580

Kamardin, H. (2014). Managerial ownership and firm performance: The influence of family directors and non-family directors. In Ethics, governance and corporate crime: challenges and consequences, Vol. 6 (pp. 47-83).

https://doi.org/10.1108/S2043-052320140000006002

Kaserer, C., \& Moldenhauer, B. (2008). Insider ownership and corporate performance: evidence from Germany. Review of Managerial Science, 2(1), 1-35.

https://doi.org/10.1007/s11846-007-0009-3

Katper, N., Shaikh, S. S., Anand, V., \& Imtiaz, N. (2018). Analysing the impact of managerial ownership on the performance of shariah-compliant firms in Pakistan. International Business Research, 11(11), 55-66. https://doi.org/10.5539/ibr.v11n11p55

Khan, A., Mather, P. R., \& Balachandran, B. (2014). Managerial share ownership and operating performance: Do independent and executive directors have different incentives. Australian Journal of Management, 39(1), 47-71.

https://doi.org/10.1177/0312896212463152

Khan, F. U., \& Nouman, M. (2017). Does ownership structure affect firm's performance? Empirical evidence from Pakistan. Pakistan Business Review, 19(1), 228-250.

Kidwell, R. (2008). Adelphia communications: The public company that became a private piggy bank, a case of fraud in the Rigas family firm. In S. Matulich \& D. M. Currie (Eds.), Handbook of frauds, scams and swindles: Failures of ethics in leadership (pp. 191-206). Taylor and Francis Group. https://doi.org/10.1201/9781420072860.sec5

King, M. R., \& Santor, E. (2008). Family values: Ownership structure, performance and capital structure of Canadian firms. Journal of Banking \& Finance, 32(11), 2423-2432. https://doi.org/10.1016/j.jbankfin.2008.02.002

Laeven, L., \& Levine, R. (2007). Complex ownership structures and corporate valuations. The Review of Financial Studies, 21(2), 579-604. https://doi.org/10.1093/rfs/hhm068

La Porta, R., Lopez-de-Silanes, F., Shleifer, A., \& Vishny, R. (2000). Investor protection and corporate governance. Journal of Financial Economics, 58(1), 3-27.

https://doi.org/10.1016/S0304-405X(00)00065-9

Lee, K., Peng, M. W., \& Lee, K. (2008). From diversification premium to diversification discount during institutional transitions. Journal of World Business, 43(1), 47-65. https://doi.org/10.1016/j.jwb.2007.10.010

Li, D., Moshirian, F., Nguyen, P., \& Tan, L. W. (2007). Managerial ownership and firm performance: Evidence from China's privatisations. Research in International Business and Finance, 21(3), 396-413. https://doi.org/10.1016/j.ribaf.2007.02.001

Lins, K. V. (2003). Equity ownership and firm value in emerging markets. Journal of Financial and Quantitative Analysis, 38(1), 159-184. https://doi.org/10.2139/ssrn.214909

Martin, G., Gomez-Mejia, L. R, Berrone, P., \& Makri, M. (2017). Conflict between controlling family owners and minority shareholders: Much ado about nothing? Entrepreneurship Theory and Practice, 41(6), 999-1027. https://doi.org/10.1111/etap.12236

McKee, D., Madden, T. M., Kellermanns, F. W., \& Eddleston, K. A. (2014). Conflicts in family firms: The good and the bad. Sage handbook of family business. Sage. https://doi.org/10.4135/9781446247556.n26

Morck, R., Shleifer, A., \& Vishny, R. W. (1988). Management ownership and market valuation: An empirical analysis. 
Journal of Financial Economics, 20, 293-315. https://doi.org/10.1016/0304-405X(88)90048-7

Mueller, E., \& Spitz, A. (2001). Managerial ownership and firm performance in German small and medium-sized enterprises. Corporate Finance, Capital Structure \& Payout Policies. https://doi.org/10.2139/ssrn.327567

Nguyen, T., Locke, S., \& Reddy, K. (2015). Does boardroom gender diversity matter? Evidence from a transitional economy. International Review of Economics \& Finance, 37, 184-202. https://doi.org/10.1016/j.iref.2014.11.022

Pant, M., \& Pattanayak, M. (2007). Insider ownership and firm value: Evidence from Indian corporate sector. Economic and Political Weekly, 42(16), 1459-1467. https://www.jstor.org/stable/4419499

Ruan, W., Tian, G., \& Ma, S. (2011). Managerial ownership, capital structure and firm value: Evidence from China's civilian-run firms. Australasian Accounting, Business and Finance Journal, 5(3), 73-92. https://ro.uow.edu.au/aabfj/vol5/ iss3/6

Shahab-u-Din, \& Javid, A. Y. (2011). Impact of managerial ownership on financial policies and the firm's performance: evidence Pakistani manufacturing firms. International Research Journal of Finance and Economics, 81(1), 13-29. https://mpra.ub.uni-muenchen.de/37560/

Villalonga, B., \& Amit, R. (2006). How do family ownership, control and management affect firm value? Journal of Financial Economics, 80(2), 385-417.

https://doi.org/10.1016/j.jfineco.2004.12.005
Vintilă, G., \& Gherghina, Ş. C. (2015). Does ownership structure influence firm value? An empirical research towards the $\mathrm{Bu}-$ charest Stock Exchange-listed companies. International Journal of Economics and Financial Issues, 5(2), 501-514. http://ideas.repec.org/a/eco/journ1/2015-02-23.html

Waseemullah, Ali, S., \& Mehmood, S. (2017). Impact of excess control, ownership structure and corporate governance on firm performance of diversified group firms in Pakistan. Business \& Economic Review, 9(2), 49-72. https://doi.org/10.22547/BER/9.2.3

Waseemullah, \& Hasan, A. (2018). Business group affiliation and firm performance - Evidence from Pakistani listed firms. The Pakistan Development Review, 57(3), 351-371. https://doi.org/10.30541/v57i3pp.351-371

Wellalage, N. H., \& Locke, S. M. (2014). Ownership structure and firm financial performance: Evidence from panel data in Sri Lanka. Journal of Business Systems Governance \& Ethics, 7(1). https://doi.org/10.15209/jbsge.v7i1.214

Young, M. N., Peng, M. W., Ahlstrom, D., Bruton, G. D., \& Jiang, Y. (2008). Corporate governance in emerging economies: A review of the principal-principal perspective. Journal of Management Studies, 45(1), 196-220. https://doi.org/10.1111/j.1467-6486.2007.00752.x

Zondi, S., \& Sibanda, M. (2015). Managerial ownership and firm performance on selected JSE listed firms. Corporate Ownership \& Control, 12(3-2), 233-241. https://doi.org/10.22495/cocv12i3c2p3 